\title{
Quaternary geologists win timescale vote 消滅の危機から救われた「第四紀」
}

2006 年、天文学者たちは冥王星を惑星 の座から降格させて準惑星とした。これ とは対照的に、地質学者たちは今回、議 論があった「第四紀」を、新たな定義 を与えて存続させることになった。「第四 紀」というのは、ヒトの出現から現在ま でを含む最も新しい地質年代区分（紀： period）をさす。この決定は長年続いた 論争を決着させた一方で、一部の研究者 に疎外感を抱かせることにもなった。

国際地質科学連合 (IUGS) の下部組織 である国際層序委員会 (ICS) は 5 月 21 日に投票結果を発表、存続させるべきか どうか論争が続いていた「第四紀」とい う年代区分を存続させるとともに、その始 まりを 260 万年前と定め、その前半にあ たる更新世の始まりも、従来の 180 万年 前から 260 万年前とすることを正式に決

\section{変更された地質年代区分 \\ 国際層序委員会（ISC）は第四紀の新しい} 定義を承認した。

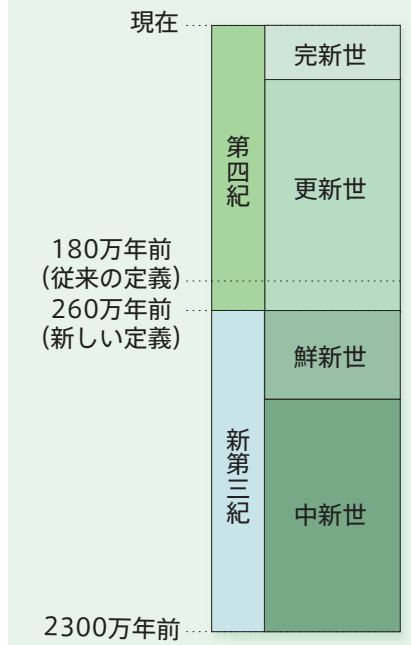

(図上の長さは時間の長さに比例していない)
定した（「変更された地質年代区分」を参 照)。この決定は7月か8月にIUGSの 理事会に報告され、承認される見通しだ。

今回の票決により、これまで新第三紀の 後半にあたる鮮新世の最後の 80 万年分 が第四紀の前半の更新世の最初に移るこ とになる。2001 年からこの再定義を求め て運動してきた英国ケンブリッジ大学の地 質学者Philip Gibbard は、「お隣さんの 領地を奪い取ったような格好になりました が、私たちからみれば、25 年から 30 年 前の間違いを訂正しただけです」と語る。

彼が「間違い」とよんだのは、1985 年に、 南イタリアの海成層を基準として更新世の 始まりが 180 万年前と定められたこと。ー 部の地質学者は、これは一地方しかみて いない恣意的な境界であり、地球全体の 変化を反映したものではないと感じ、地球 全体の温度が下がった 260 万年前を更新 世の始まりとするよう主張してきた。

もともと第四紀という言葉は1800 年代 初期に使われるようになった。地質学者 は当初、化石記録に基づいて地質年代を 第一紀、第二紀、第三紀、第四紀の 4 つ に区分した。これらのうち、第一紀と第二 紀という用語は遠い昔に使われなくなり、 第三紀という用語も、今でもときどきは使 われるものの、公式用語ではなくなってい る。現在では、新生代は古第三紀、新第 三紀、第四紀の3つに分けられている。 数十年前からは、第四紀という用語まで 過去の遺物と考える地質学者も出てきた。 実際、2004 年の万国地質学会 (IGC) で は、ICSが作成した地質年代表から第四 紀が消え、新第三紀が現代まで延長され るという“事件”も起きた。こうした動き
に第四紀学の研究コミュニティーは公然と 反発した。

$$
\text { カリフォルニア州立大学ロングビーチ校 }
$$
の地質学者で、ICS の委員長である Stan Finney は、「地質年代表は地球の歴史を 表すための基本です。私たちの時計なの です。ですから、基本単位になる年代区 分とその境界は、正確に定義されていな ければならないのです」と話す。

Finney 2008 年にICS 委員長に就任 したときにこの論争を引き継ぎ、民主的 なプロセスで問題を解決すると約束した。 数か月にわたって率直な意見交換が行わ れ、第四紀学と新第三紀学の研究コミュ ニティーから正式な提案を受けつけた後、 4 月と 5 月に 2 回の投票が行われた。そ の結果、「第四紀という年代区分を存続さ せて、その始まりの時期を変更する」とい う提案が 18 人の投票委員のうち 16 人の 賛成で承認された。

一部の研究者は議論が決着したことを 歓迎したが、そうでない研究者もいる。 米国地質調査所（バージニア州レストン） の海洋地質学者 Lucy Edwardsは、「パ リのメートル原器を持ってきて、それに 40 センチもつけ加えるようなことは普通 はしないでしょう。より厳密に定義するた めの再定義なら歓迎ですが、期間を $40 \%$ も増やすなど、考えられないことです」と 話す。Edwardsには現実的な懸念もある。 1980 年代に更新世を 180 万年前とする 決定がなされたとき、米国地質調査所は、 作成したすべての地図を改訂し、用語を 書き換えなければならなかった。今回、 国際的な基準が変わったら、またまた同じ 作業をしなければならない。 
ラトガーズ大学ピスカタウェイ校 (ニュー ジャージー州）の Marie-Pierre Aubry は、 今回の変更に反対してきた。彼女は、「今 回の決定では学界のルールが破られた」 と主張する。「地質年代の他の主要な境 界は、動物相の絶滅や交代ときちんと対 応しています。しかし、新第三紀と第四紀 の境界にはそうしたものが何もないので
す」。彼女はまた、多くの教科書では、現 在を含む地質年代は第四紀ではなく新第 三紀と呼ばれているとも指摘する。新第三 紀学の研究コミュニティーは既に変更案の 承認の票決を延期するようIUGS に要請し ている。

変更を受け入れた研究者もいる。オー ストラリアのウエスタンオーストラリア州
地質調査所（同州イーストパース）の地 質学者で、変更案に反対票を投じた 2 人の投票委員の 1 人である Martin Van Kranendonk は、「これは学術用語の変更 にすぎません。地層や地球の歴史は何も 変わっていないのです。つまり、私たちが それを何とよぶかという問題にすぎないの です」と話している。(新庄直樹 訳) 